\title{
The Poet and the Prince: Revising Molière and Tartuffe in the French Revolution
}

\author{
Mechele Leon
}

Le paradoxe de Molière, à l'apogée de sa vie, fut d'être à la fois homme de pouvoir et de contestation. Personnage officiel en même temps que marginal, il se trouva sans cesse au centre de luttes, dont les négociations pour obtenir son enterrement chrétien ne constituèrent pas le dernier épisode.

Michel Delon

An array of contradictory elements surrounded Molière, but the paradox of his having been both powerful and persecuted acquired special resonance during the French Revolution. Molière's legendary association with Louis XIV and the royal patronage long deemed integral to his artistic success came to the fore in the context of revolutionary anxiety about the culture inherited from the Old Regime-culture at once useful and stained by its association with a rejected past. Molière's ties to the monarch emerged in published debates that raged early in the Revolution about the proper relationship between government and theater. This literature suggests the construction of a new narrative of the poet's life story in which he owes little or nothing to his sovereign. Documents also reveal that performance texts of Tartuffe were altered during the revolutionary period to excise the role of the monarch. Together, the reconfiguration of Molière's relationship to Louis XIV and the modifications to Tartuffe may be interpreted as complementary processes of revision-one historical, the other literary. They are parallel efforts by revolutionaries to void their cultural inheritance of all

\footnotetext{
Mechele Leon is assistant professor of theater at the University of Kansas. She is currently working on the manuscript of her first book, "Molière and the French Revolution."

The author wishes to thank Jacqueline Razgonnikoff of the archives of the ComédieFrançaise, the members of the Performance Research Study Group at the University of Kansas, Leslie Tuttle, Bruce Hayes, and the editors and anonymous reviewers of French Historical Studies for their thorough and insightful suggestions.
} 
traces of Old Regime legitimacy. They are also mutually illustrative of the tenacious nature of the Old Regime political culture embedded in the artifacts revolutionaries so passionately sought to reform.

In this article, I examine both sides of this revisionist coin. My interpretation of the significance of revolutionary revisions to Molière's life and works is informed by Robert Darnton's work on related phenomena. In research presented to the American Society for EighteenthCentury Studies in 1989, Darnton offered the intriguing thesis that "one of the most important tasks of the French Revolution was to rewrite Molière." "What led Darnton to this bold conclusion was his analysis of the revolutionary play by Fabre d'Eglantine, Le Philinte de Molière, ou Suite $d u$ "Misanthrope." It was so important to rewrite Molière, goes Darnton's argument, because society itself was being rewritten. Revising the literature of the Old Regime was integral to fashioning a new society: "The French Revolution was a literary revolution." Revolutionaries tried to reconstruct their reality "from the rubble of an old regime" and so began with the "sacred center of the old literary system - the space shaped by Molière." ${ }^{2}$

Darnton's interest in Molière's fate during the Revolution was certainly justified. Thanks to extensive quantitative research into the repertory performed in the Parisian theater between 1789 and 1799, we now know that his plays became enormously popular once theater enterprise was liberated and the Comédie-Française lost its century-long privilege as exclusive presenter of his comedies. ${ }^{3}$ Nearly two thousand performances of them were given; L'école des maris, Dépit amoureux, and Le médecin malgré lui figure among the ten most performed plays during the Revolution, and Molière's comedies were produced in more theaters than those of any other author. Unfortunately, little is known about his plays in performance - acting styles, for example, or "corrections" to his texts - or about their reception. ${ }^{4}$

1 Robert Darnton, What Was Revolutionary about the French Revolution? (Waco, TX, 1989), 21.

2 Ibid., 38-41.

3 Emmet Kennedy et al., Theatre, Opera, and Audiences in Revolutionary Paris: Analysis and Repertory (Westport, CT, 1996). These data are now incorporated into the Calendrier électronique des spectacles sous l'Ancien Régime et sous la Révolution, www.cesar.org.uk. See also André Tissier, Les spectacles à Paris pendant la Révolution: Répertoire analytique, chronologique et bibliographique, de la réunion des Etats Généraux à la chute de la royauté, 1789-1792 (Geneva, 1992); and Tissier, "Les représentations de Molière pendant la Révolution," in Eighteenth-Century French Theater: Aspects and Contrasts, ed. Magdy Gabriel ([Edmonton], Alberta, 1986), 119-36.

4 The theater press during the Revolution was focused mainly on productions of new drama; relatively rarely would commentators remark on performances of Molière's plays. Studies about Molière in the revolutionary era consequently lean toward quantitative methodologies. In addition to the studies mentioned above, see Roger Barny, "Molière et son théâtre dans la Révolution," Bulletin d'histoire de la Révolution française (1994-95): 43-63, 65-79. One exception to this is Otis Fellows, "Molière à la fin du siècle des Lumières," in Age of Enlightenment: Studies Presented to Theodore 
As Darnton's work suggests, the revolutionary treatment of Molière's Misanthrope is significant as an example of what contemporary revolutionary historiography understands as the era's defining political strategy, namely, inventing a complete break with the past. Within this historiography, theater (broadly defined to include art, event, gathering, performance technique, and dramatic literature) has come to be regarded as crucial to an understanding of the genesis and contradictory workings of revolutionary political culture. ${ }^{5}$

If Darnton helps us situate revisions of Molière's plays squarely within the context of revolutionary political culture, it is important to add that the notion of rewriting Molière can be found in other domains of his revolutionary afterlife: in plays and theatrical performance, of course, but also in biography, dramatic criticism, political discourse, iconography, and memorializing events. In contrast to the respectful drames of the prerevolutionary period, for example, revolutionary biographical dramatic literature depicted Molière not as an acolyte of the court but as a man of the people, drawing inspiration from the common folk and rejecting aristocratic values. ${ }^{6}$ The revolutionaries did not stop at revising his corpus: they exhumed his corpse with the explicit intention of avenging the ignoble burial given him under the Old Regime. ${ }^{7}$

Besterman, ed. W. H. Barber et al. (Edinburgh, 1967), 330-49. Fellows surveys a variety of topics and concludes that Molière's reception during the Revolution was "equivocal."

5 Darnton's assessment of literature as central to revolutionary politics reflects a methodological sea change that shifted the focus for many historians of the French Revolution from socioeconomic determinants to the discursive practices that embody and reveal the ideological underpinnings of revolutionary politics. One result of this shift in focus has been to put attention as never before on the theater. Studies most directly reflecting this shift include Marie-Hélène Huet, Rehearsing the Revolution (Berkeley, CA, 1982); Susan Maslan, "Resisting Representation: Theater and Democracy in Revolutionary France," Representations 52 (1995): 27-51; and Paul Friedman, Political Actors: Representative Bodies and Theatricality in the Age of the French Revolution (Ithaca, NY, 2002). Exhaustive quantitative research undertaken on the repertory of plays and operas performed in Paris from 1789 to 1799 and presented in Theatre, Opera, and Audiences, however, has proved that performances of plays written prior to the Revolution-particularly the corpus of Old Regime comedies, in which Molière's works figure so prominently-far outnumbered those of plays written during the Revolution. Given that the plays most often performed on the revolutionary stages of Paris had nothing to do with the politics of the day, Kennedy and coauthor Marie-Laurence Netter argue, it follows that audiences wanted simple entertainment: light, amusing, and frivolous. Rather than a theater that spoke to the events and concerns of the time, it was, grosso modo, "oblivious to the Revolution" (34). I criticize this position in my review of Kennedy and Netter's book in Theatre Insight 9, no. 2 (1998): 71-73, in which I cite Pierre Frantz's salient point that a play "can take, in the context of its revolutionary mise-en-scène, meanings that its mere inscription on the repertory does not reveal" ("Pas d'entracte pour la Révolution," in $L a$ carmagnole des muses, ed. Jean-Claude Bonnet [Paris, 1988], 390).

6 A chapter in my book manuscript in progress is devoted to biographical plays about Molière. Several of these plays appeared in the form of vaudevilles and demonstrate a marked shift in theme and emphasis from the plays of Louis-Sébastien Mercier, La maison de Molière (1787), and Michel Cubières-Palmezeau, La mort de Molière (1788).

7 What were believed to be Molière's remains were exhumed in July 1792. The Parisian section calling itself "Molière and La Fontaine" - one of forty-eight centers of community governance 
In this sense, we can broaden the notion of what constitutes "rewriting Molière" to include both text and author. Doing so provides an important methodological opportunity, one that Dominick LaCapra describes as exploring the "mutually challenging interaction" between the study of history and literature. ${ }^{8}$ What is beneficial about this dialogical interaction is not that it validates or harmonizes discoveries between these domains but that it can uncover the disarticulations, the fault lines, in seemingly coherent phenomena in both domains. The rewriting of Molière's plays, this article aims to show, should be considered in tandem with the rewriting of his life history, because literary revision helps expose the lingering presence of ideas and structures that revisions of history may occlude.

Reflecting this two-pronged approach, the first part of this article considers debates concerning the theater early in the Revolution to analyze how revolutionaries articulated the relationship between Molière and Louis XIV. They sought to liberate theater enterprise and end the monopolies on different dramatic genres held by the privileged theaters. The issue at stake was how to write legislation to replace the long tradition of royal authority over the theater. Molière's relationship with Louis XIV, as I discuss below in a brief summary of his professional biography, was a strange combination of both extraordinary benefit and frustrating inconsistency. This complex relationship between the poet and the prince was promptly seized on by revolutionaries eager to use it to shore up arguments for theater regulation in the name of a new regime.

The second part of this article considers the implications of revisions to Tartuffe in the revolutionary theater. ${ }^{9}$ Although censorship of dramatic literature as it was practiced under the Old Regime officially ended in 1791, it became common for theater practitioners to "correct" Old Regime plays still deemed acceptable for the stage. According

during the Revolution - that initiated the exhumation intended to honor him with a sepulchral monument in the chapel adjoining the cemetery. Instead, his bones were moved from one place to another for seven years before Alexandre Lenoir laid them to rest in the garden of the Musée des Monuments Français. The exhumation of Molière is one of the more intriguing events in his afterlife, and one I analyze in my book in terms of the tension between history and memory. A thorough account of the exhumation is provided by Louis Moland, "Histoire des restes mortels de Molière," Revue de la Révolution 2 (1883): 405-25.

8 Dominick LaCapra, "Reconfiguring French Studies," in History and Reading: Tocqueville, Foucault, French Studies (Toronto, 2000), 169.

9 The matter of Tartuffe during the Revolution has attracted the attention of literary historians, most notably William D. Howarth, "Les 'Tartuffes' de l'époque révolutionnaire," in Il teatro e la Rivoluzione francese: Atti del convegno di studi sul teatro e la Rivoluzione francese, Vicenza, 14-16 settembre, 1989, ed. Mario Richter (Vicenza, 1991), 65-77. Howarth focuses on revolutionary-era plays that imitate Tartuffe in their portrayal of social or political hypocrisies. My approach focuses on revisions to the play itself. 
to the little evidence we have, these corrections ranged from the relatively innocuous substitution of citoyenne for madame to more substantive alterations of language, character, and plot. Despite their popularity, Molière's plays were not spared the vilification heaped on the Old Regime dramatic repertory during the Terror. ${ }^{10}$ In May 1794 the Committee of Public Instruction reestablished preemptive censorship by ordering theaters to submit their repertory lists to government committees for approval. Almost all of Molière's plays were declared unacceptable. Tartuffe was an exception; it was admitted "with revisions." 11 While the precise nature of these revisions is unknown, they appear to have affected most specifically the denouement of the play-an exemplary deus ex machina in which the king intervenes, by proxy of a royal officer, to exonerate Orgon and rescue him from the hypocrite Tartuffe. This article shows different strategies that the revolutionaries employed to excise the sovereign from the play. My analysis of the inconsistencies introduced by these "corrections" suggests that rewriting Molière was less an instance of revolutionizing Old Regime literature than an illustration of this literature's ability to sustain Old Regime political culture.

\section{Revising History}

The history of the paradoxically powerful/persecuted Molière begins with the return of his company to the capital after thirteen years of touring the provinces following his failed attempts to establish a theater in his native Paris between 1643 and 1645. ${ }^{12}$ After performing before the court in October 1658, Molière was granted a theater at the Petit-Bourbon palace, which his company, under the patronage of the king's brother, was to share with the Italian players then in residence. The actors and playwrights of the premier theater of Paris, the Hôtel de Bourgogne, were less than pleased about the competition from

10 Two important studies by André Lieby discuss the fate of the Old Regime dramatic repertory during the Revolution: "La presse révolutionnaire et la censure théâtrale sous la Terreur," Révolution française 45 (1903): 306-53, 447-70, 502-29; 46 (1904): 13-28, 97-128; and "Lancien répertoire sur les théâtres de Paris à travers la réaction thermidorienne," Révolution française 49 (1905): 146-75, 193-219. See also Beatrice Hyslop, "The Theater during a Crisis: The Parisian Theater during the Reign of Terror," Journal of Modern History 17 (1945): 332-55; and Suzanne J. Bérard, "Aspects du théâtre à Paris sous la Terreur," Revue d'histoire littéraire de la France 4-5 (1990): $610-21$.

11 Records of the Committee's work on these repertory lists were destroyed by fire during the Commune. According to the researcher who consulted the documents in 1844, in the space of three months 151 plays were examined, 33 were rejected, and 25 were accepted with revisions. Auguste Vivien, "Etudes administratives III: Les théâtres et leur situation actuelle en Angleterre et en France," Revue des deux mondes, n.s., 6 (1844): 399.

12 The summary that follows draws on a number of biographies, including, most recently, Virginia Scott, Molière: A Theatrical Life (Cambridge, 2000). 
the Troupe de Monsieur. While they and their sympathizers took little notice of Molière's company when it began performing in November 1658, the success of Les précieuses ridicules a year later brought Molière to their attention and began the attacks that would plague him throughout his career.

Criticism of Molière's plays during his lifetime was as varied as his repertory. Clearing away the nuances, however, it came down to a few basic accusations: that Molière's work was artless, unoriginal, obscene, and irreligious. Although severe, much of this criticism was in keeping with aesthetic, moral, and religious concerns of the time. So why the enduring image of Molière as persecuted? To many in the eighteenth century, the negative assessments of Molière by his contemporaries appeared both harsh and specious. They were understood to be the product of cabals led by powerful rivals whose agendas had little to do with his plays. While commentators of the Enlightenment questioned the salutariness of his plays, they did so on social, not religious, grounds. The church's condemnation of the theater $-\mathrm{a}$ centuries-old obsession - made the clergy's attacks on Molière appear a matter of sweeping parochial policy.$^{13}$ More egregiously, Molière's enemies launched personal attacks on him. He was ridiculed in the plays $L e$ portrait du peintre (1664) and Elomire hypochondre (1670). As an actor, his detractors charged, he was incapable of playing anything but a clown; his formidable comic skills were nothing more than aping of the great Italian farceur Scaramouche, leading actor of the Comédie-Italienne in Paris. ${ }^{14}$ Molière was also mocked as a beleaguered husband, a cuckold worthy of the most memorable cocus in his own plays. He was accused, in barely disguised terms, of marrying his own daughter.

Louis XIV was Molière's powerful ally against the onslaught of professional criticism and personal calumnies that plagued him throughout his career in Paris. Molière's company was favored at the court: twenty-eight of his thirty-two plays were performed there, and most of them premiered before the king. Molière's talents were placed at the center of elaborate festivals staged at the palaces of Versailles, Saint-Germain-en-Laye, Vincennes, Fontainebleau, and Chambord. Louis XIV supported Molière in real and symbolic ways at strategic moments in his career. At the height of the controversy over L'école

13 For an excellent comprehensive analysis of eighteenth-century opinion of Molière, see Monique Wagner, Molière and the Age of Enlightenment (Banbury, U.K., 1973).

14 The frontispiece to Elomire (an anagram of "Molière"), for example, sported the engraving "Scaramouche enseignant, Elomire étudiant" and depicted Molière with a mirror in his hand trying to reproduce Scaramouche's grimaces. Molière, Oeuvres complètes, ed. George Couton (Paris, 1971), 2:1551n. References to the plays are to act, scene, and line in this edition. 
des femmes in June 1663, the monarch awarded the playwright and his company generous pensions, to be renewed annually. Molière immediately brought this victory to the attention of his rivals by publishing his Remerciement au Roi. Molière also publicized the king's active interest in his plays. In the dedication to Les fâcheux (1661) Molière thanked Louis XIV for his contribution to the play. The monarch had suggested that he add a character to the parade of pretentious pests and bores that populate this piece-a character "qui a été trouvé partout le plus beau morceau de l'ouvrage [found by all to be the finest part of the play]," Molière remarked (1:481). Not long after a rival actor had accused Molière of incest, the sovereign became the godfather of the playwright's son Louis, born in February 1664. During the battles that raged over Tartuffe, the king gave Molière's company seven thousand livres and awarded them the title of Troupe du Roi. But Louis XIV's support for Molière was not consistent. When in 1672 he gave JeanBaptiste Lully, the Italian-born composer with whom Molière collaborated on many of his comédie-ballets, exclusive privilege to musical performance, Molière was forced into the humiliating position of seeking permission from the king to maintain a small orchestra and dancers for his theater. A year later Molière's wife, Armande, had to petition Louis XIV to intervene against the church's decision to deny her husband a Christian burial. The monarch remained silent on the matter.

The defining event in the history of Molière's association with Louis XIV was undoubtedly his five-year battle to bring Tartuffe to the public stage. The facts are well known: Molière presented a performance of his three-act play Tartuffe, ou Lhypocrite to Louis XIV at Versailles in May 1664. Although reportedly the king was impressed by the play, he deemed it politically unwise to allow public performances of it. Over the next several years and with the monarch's tacit approval, Molière continued to revise the play and gave several private performances at the command of Condé. Meanwhile, the powerful dévots used their influence to keep the play from the public. In August 1667 Molière, having the verbal consent of the king, presented the five-act Panulphe, ou L'imposteur at his theater in Paris. Louis XIV was with his army in Flanders at the time. In his absence the city was under the authority of Guillaume de Lamoignon, president of the Parlement of Paris and a prominent member of the Compagnie du Saint-Sacrement, a secret and militant Catholic society. Lamoignon promptly forbade a second performance of the play and obtained an interdiction from the archbishop of Paris stating that anyone presenting, reading, or attending this play, publicly or privately, risked excommunication. Two actors from Molière's troupe were immediately dispatched to the king's camp 
in Lille with a petition from Molière. They obtained the sovereign's promise that he would consider the matter as soon as he returned to Paris. Shortly afterward, a lengthy description and defense of the play appeared in print in the anonymous Lettre sur la comédie de "Limposteur." With the issue now before the public, the monarch gave his consent and Tartuffe, ou Limposteur opened in February 1669 for a record number of performances before packed houses.

The denouement of Tartuffe was the coup de grâce for those enemies of Molière who believed that their machinations, like Tartuffe's, could deceive "un Prince dont les yeux se font jour dans les coeurs [a Prince who sees into our inmost hearts]" (5.7.1907). "Voici une comédie dont on a fait beaucoup de bruit, qui a été longtemps persécutée [Here is a comedy about which much fuss has been made and which has been long persecuted]," wrote Molière in the opening sentence of the preface to the play, published the same year-thus leaving for posterity both an elegant argument in his own defense and an indictment of those who opposed him (1:883). The battle for Tartuffe and Louis XIV's role in the affair were inscribed for posterity in Molière's pétitions to the king, reproduced in the first edition of his complete works (1682). For La Harpe, the denouement of Tartuffe was the best evidence of Molière's "gratitude toward Louis XIV." ${ }^{15}$ Meanwhile, the persecution he suffered at the hands of his contemporaries was a "humiliation" for the nation, according to Voltaire in Vie de Moliere. ${ }^{16}$ Similarly, La Harpe writes: "What! At the moment when you surpassed even your own genius, instead of being rewarded, you were greeted with persecution!" 17

Given this legendary history of Molière's relationship to the monarch, and particularly to the royal patronage that was widely understood to have played a central role in his career, it is not surprising that we find it recalled in the ardent debates that occurred early in the Revolution over government regulation of the theater. After July 1789 the bond between the king and the privileged theater founded in Molière's name was severed when authority over the Comédie-Française-the maison de Moliere-passed from the Crown's bureau charged with its management to the municipal government of Paris. Later that year spectators decried the interdiction of performances of Marie-Joseph Chénier's historical drama about the Saint Bartholomew's Day massa-

15 Jean-François de La Harpe, Lycée, ou Cours de littérature ancienne et moderne (Paris, 17991805), 8:287.

16 Voltaire, Oeuvres complètes (Paris, 1879), 23:119.

17 La Harpe, Lycée, 8:209. 
cres, Charles IX. Throughout 1790 playwrights, politicians, commentators, and actors voiced their opinions concerning issues pertaining to the theater: free enterprise, dramatic censorship, and the proprietary rights of authors. ${ }^{18}$ In addition to Chénier's prolific production of letters and pamphlets defending his cause, Millin de Grandmaison's $L a$ liberté du théâtre and La Harpe's Discours sur la liberté du théâtre (both 1790) were greatly influential in shaping the legislation passed in January 1791 that destroyed all but a few governmental restrictions on theater while eliminating the proprietary claims of theaters on different dramatic genres.

Molière is regularly invoked in the arguments of the theater reformers. Sometimes he is mentioned in passing, as in La Harpe's Discours supporting the rights of authors and denouncing the monopolies held by the royal theaters. "It seems to me absurd, incredible, ridiculous," writes La Harpe, "that we should believe twenty men of genius worked for over a century and a half just to nourish the laziness and vanity of a single privileged acting troupe, sole inheritor of their efforts." In the name of liberty, he continues, "all actors must be permitted to perform Racine, Crébillon, Molière, et cetera, just as any publisher is permitted to print them." 19 Chénier, in the course of condemning the subaltern status of actors, reminds his readers of the ignoble treatment accorded Molière, "a great man," who "only narrowly received a burial in France." The celebrated English actor David Garrick, Chénier writes, "was offered a seat in the House of Commons alongside the representatives of the English nation. Molière, in France, would not have been given the post of a churchwarden." 20

The history of Molière's career is given more prominence in a 1790 pamphlet arguing that, instead of liberating theaters, royal authority over theater should be replaced with strict government regulation. This pamphlet, Influence de la Révolution sur le Théâtre-Français, takes the somewhat ambiguous position that Molière owed the perfection of his art not specifically to Louis XIV but to the inspiration provided by the occasions of state theater. The anonymous author argues that, as royal authority over the Comédie-Française (Théâtre de la Nation) was now dissolved, the government should take responsibility for controlling theaters to maintain their dignity and protect the quality of the

18 G. Charles Walton, "Charles IX and the French Revolution: Law, Vengeance, and the Revolutionary Uses of History,” European Review of History 4 (1997): 127-46.

19 Jean-François de La Harpe, Discours sur la liberté du théâtre, prononcé par M. de la Harpe, le 17 décembre 1790, à la Société des Amis de la Constitution de Paris (Paris, 1790), 7.

20 Marie-Joseph Chénier, Courtes réflexions sur l'état civil des comédiens (Paris, 1789), 7-8. 
national stage from unworthy competition. Louis XIV's support for Molière illustrates the benefits of such patronage. The author asserts that Molière's art flourished by virtue of his association with the court. He describes pre-Molièrean comedy as a kind of dramaturgical dark age that amused "the imbecility of the people" with farces performed by unskilled itinerants on "boards in public squares and fairgrounds." The king's military triumphs and the court festivities that were designed to celebrate them provided both the occasion for Molière's art to flourish and the inspiration for him to perfect it: "One was obliged to sing of the conquests and celebrate the conqueror." In glorifying the king, Molière's genius was animated by "a noble ambition." Louis XIV rewarded Molière with protection and preference, defended him against rivals, and conferred on him the honor of organizing his festivals. All this, the author summarizes, "chained Molière to his king." ${ }^{21}$

The ties between Molière and Louis XIV are portrayed far less favorably in another pamphlet by Chénier, De la liberté du thêâtre en France (1789). While acknowledging that Molière received support from the monarch, the author of Charles IX considers Molière's struggle to bring Tartuffe to the stage indisputable proof of the necessity for legislation to protect theater from arbitrary censorship and equally arbitrary patronage. Chénier argues that Louis XIV eventually approved public performances of the play only because "Molière, tormented and slandered by a cabal of priests and insulted in church by Bourdaloue, knew how to flatter Louis XIV's pride and to ensure his support by inserting in his play a panegyric of him." ${ }^{22}$ Chénier then emphasizes the inconsistency of the monarch's support for Molière. Louis XIV, "weakened by age and worry" and passing his time no longer at spectacles but "between his Jesuit confessor and his Jansenist mistress," neglected Molière shamelessly in the last years of his life. "Thus everything varied in France under the despotism of those aristocrats whose yokes we now shake off. Thus the law changed from one day to the next. The slightest friend of a prince, a favored servant or courtesan, the mistress of a minister or a head clerk, could rudely challenge the law, or more rudely defend it." ${ }^{23}$

The texts I have discussed thus far allow that Molière's artistic production owed something to Louis XIV's patronage. But in an article from Révolutions de Paris in December 1790 we find an interpretation of the relationship between the poet and prince that is strikingly differ-

21 Influence de la Révolution sur le Théâtre Français: Pétition à ce sujet, adressée à la Commune (Paris, 1790), 4-5.

22 Marie-Joseph Chénier, De la liberté du théâtre en France (Paris, 1789), 10.

23 Ibid., 10-11. 
ent. In this text Molière neither flourishes under Louis XIV's patronage nor benefits from his fair-weather protection. Instead, he is painted as a cunning and audacious rebel, seething with hatred for the monarch:

Although Molière was obliged and forced to remain silent in horrible servitude, liberty seeped from his pores. Forced to praise Louis XIV, he wrote detestable prologues and broke the rules of versification. He employed platitudes and the most vulgar commonplaces intentionally so as to reveal for posterity the disgust and horror he had for a task imposed on him by circumstances, his position, and the desire to diffuse his talents and ideas. Read The Impromptu at Versailles and judge for yourself. His cynicism and disdain, shielded by an exquisite and sublime talent, found the means to express themselves, even to the point of reproaching Louis XIV for puerile vanity, despotism, and the domination of nobles. And this he did right to his [Louis's] face, making the prince laugh at his own ridiculousness. ${ }^{24}$

This passage is fascinating for its configuration of Molière as a kind of republican avant la lettre, sending a message in a bottle to be fished out by some future free society capable of deciphering its code. Instead of willingly serving his king, Molière is depicted here as antagonistic to him. Never, declares the journalist, has anyone been "more ahead of his time." It is worth noting that this opinion is strikingly different from one expressed only two years before. In an argument invoking similar prescience - this time attributed to Molière's royal patron-Grimod de La Reynière writes that "Louis XIV, who loved art and recognized it in men, foresaw that Molière would immortalize his reign. He was consistently his protector and supporter. He stood behind him with all his authority against les faux-dévots, les précieuses ridicules, ignorant doctors, and impertinent boors. Without the resolve of this prince, Tartuffe never would have been performed." 25

Presenting a portion of the Révolutions article under the section heading "Le courtisan malgré lui," Paul d'Estrée describes the opinion as a "grotesque" interpretation of Molière's works. ${ }^{26}$ But neither d'Estrée nor Marvin Carlson after him provides the full context in which these remarks appear. ${ }^{27}$ They are found in a long footnote to an article in which the author urges the National Assembly to cease its delay in rendering legislation on the theater. He argues that the government should be deeply concerned with theater because drama has

24 Révolutions de Paris, no. 74 (1790): 457-58n.

25 A.-B.-L. Grimod de La Reynière, Peu de chose: Hommage à l'Académie de Lyon (Paris, 1788), 14. 26 Paul d'Estrée, Le théâtre sous la Terreur (Paris, 1913), 415-16.

27 Marvin Carlson, Theater of the French Revolution (Ithaca, NY, 1966), 84. 
proven to be enormously beneficial to the nation. Tartuffe is the case in point: the Jesuits would never have been expelled from France if Molière's chef d'oeuvre had not opened the public's eyes to "the hypocrisy, greed, charlatanism, and cruelty of that terrible sect." ${ }^{28}$

This "grotesque" characterization of Molière as a protorepublican occurs alongside the argument to abolish monarchial authority over the theater. Admittedly, the opinion expressed by the journalist is extreme, but it is not unlike efforts, such as those of Chénier, to represent a Molière whose professional career owed little or nothing to royal patronage. It is no more grotesque to recast Molière as a seething critic of despotism than it is to depict Tartuffe as revolutionary literature. The interpretation of Tartuffe as a drama effecting a radical change in a corrupt society harmonized with the notion of Molière as foreign to the world in which he produced his works. As for Tartuffe in this new context, the record of censored drama in 1794 indicates that all that was needed for approval of the play during the Terror were some "corrections." Revising history, however, is not revising literature. Taking Molière out of the Old Regime would prove easier than taking the Old Regime out of Tartuffe.

\section{Revising Literature}

"In the course of all these crises," wrote a leading actor of the ComédieFrançaise about the Terror, "what became of the theater? We sansculottized [ sans-culottisa] it as we sansculottized everything. Our masterpieces underwent purifying scrutiny. . . . We mutilated Corneille. . . . We even dared to lay a sacrilegious hand on Molière." ${ }^{29}$

As it concerned Tartuffe, defiling Molière meant tampering with the denouement of the play. It is common to regard the ending of Tartuffe as effected by a deus ex machina. The miserable Orgon, on the verge of losing his home and freedom to the impostor, is saved when the king's officer (the Exempt), accompanying Tartuffe ostensibly for the purpose of arresting Orgon, arrests Tartuffe instead. The king by proxy of his officer is therefore that "character external to the plot who intervenes in extremis to resolve an apparently insoluble intrigue." In fact, the Dictionnaire encyclopédique du théâtre, in which this definition appears, refers the reader to Tartuffe as the exemplar. ${ }^{30}$

28 Révolutions de Paris, no. 74 (1790): 457.

29 Fleury [Joseph Abraham Bénard], Mémoires de Fleury de la Comédie-Française, ed. Henri d'Alméras (Paris, 1903), 239-40.

30 Dictionnaire encyclopédique du théâtre, ed. Michel Corvin (Paris, 1995), s.v. "deus ex machina." 
A few points of plot about this unusual intervention at the end of the play: Orgon technically does not have a case against eviction from his home and arrest. In anticipation of marrying Tartuffe to his daughter, and after banishing his son from his home, Orgon deeds Tartuffe his house and fortune with a contract "en bonne forme [in proper form]" that "on n'y peut rien dire [one cannot question]" (5.4.1757). Furthermore, Orgon, in possession of a strongbox containing secret papers belonging to an exiled friend, entrusts the incriminating coffer to Tartuffe "par un motif de cas de conscience [by a scruple of conscience]" (4.1.1585). Thus Orgon has been cornered by Tartuffe, as he will discover when he tries to order him from his house. To extricate Orgon from this situation will require an extralegal solution. The monarch annuls Tartuffe's contractual claim on Orgon's home and exonerates Orgon for aiding an exile. He does so at the last moment and to the surprise of all. The king's intervention, as La Harpe correctly points out, introduces "a foreign jurisdiction" to the play. The intervention is necessary, however, because Tartuffe "cannot be punished by the law." ${ }_{1}$ Modifications to the denouement of the play that were made during the revolutionary period, however, sought to do just that. The inconsistencies that surface in the text as a result of the attempt to replace the sovereign's will with republican justice demonstrate the difficulties inherent in the revolutionary political dream of erasing the past.

As a practical matter, eliminating the king from the denouement of the play is all the more difficult because of the officer's speech in the final moments of the play. Forty lines extol the virtues of the prince. ${ }^{32}$ While no definitive evidence exists about alterations made to the text for performance, ${ }^{33} \mathrm{a}$ few telling indications about changes appear in contemporary sources. Historians of the revolutionary theater have noted Cailhava's remarks that the opening verses of the officer's speech,

Nous vivons sous un Prince ennemi de la fraude,

Un Prince dont les yeux se font jour dans les coeurs,

Et que ne peut tromper tout l'art des imposteurs

[We live under a prince who despises fraud, a prince who can read into the hearts of men, who is not fooled by the impostor's art] (5.7.1905-7)

31 La Harpe, Lycée, 8:286.

32 As the discussion that follows focuses closely on the officer's speech from Tartuffe, I include the entirety of this speech in French as an appendix.

33 No researcher has yet uncovered manuscript evidence of changes to Tartuffe for performance in the revolutionary theater. This is not true for Phaedra and The Misanthrope. See Antonio Sergi, "Phèdre corrigée sous la Révolution," Dix-huitième siècle 6 (1974): 153-65; and Jules Janin, "Le Misanthrope' de Molière en 1793 d'après un exemplaire approprié à cette époque," Journal des débats politiques et littéraire, Aug. 12, 1833, 1814-55. 
were replaced in performance with the lines

Il sont passés, ces jours d'injustice et de fraude,

Où doublement perfide, un calomniateur

Ravissait à la fois et la vie et l'honneur

[They have passed, those days of injustice and fraud,

When a slanderer, doubly perfidious,

Devoured both life and honor]. ${ }^{34}$

Cailhava does not indicate precisely when these changes were introduced, but evidence suggests that they date from late 1793 or early 1794. This is confirmed in a report by a police agent who attended a production of Tartuffe in January 1794 at the Théâtre de la République. From the agent's description of the play, it appears that the officer's speech was cut in its entirety; indeed, the play was markedly altered following Tartuffe's entrance in the final scene. According to the report, Tartuffe calls on the officer to arrest Orgon for harboring "unpatriotic [incivique] intentions in collusion with the enemies of the Fatherland." This anachronistic denunciation received "most enthusiastic applause" from the public. In the ending's surprise reversal, "a municipal officer" arrests Tartuffe with words, according to the agent, "that should be engraved in the hearts of all true republicans: 'Your villainous schemes are discovered, and no longer does a vile slanderer rule over the lives of true patriots. Follow me!'”35

Purely in terms of plot, accusing Orgon of treason is in keeping with Molière's Tartuffe; Orgon is culpable of aiding a traitor. What is curious here is the report that, on hearing the perfidious Tartuffethe villain of the play-make his accusations against Orgon, the audience broke out in "enthusiastic applause." Audiences attending a performance of Molière's play without such "corrections" to the text might be impressed with Tartuffe's audacity and cunning, but an act of incriminating Orgon would hardly elicit approval. How can we understand the incongruity in the revolutionary audience's energetic endorsement of the acts of a hypocrite in one moment and of his ruin in the next? In part, this incongruity may reflect the exceptional logic of the revolutionary government after the Convention suspended the constitution in October 1793. The law lost its authority in favor of "the circumstantial necessity of arbitrary violence against the enemies of liberty." ${ }^{6}$ The

\footnotetext{
34 Jean-François Cailhava d'Estendoux, Etudes sur Molière (Paris, an X [1802]), quoted in d'Estrée, Théâtre sous la Terreur, 8, and Carlson, Theater of the French Revolution, 158.

35 Report of 13 nivôse II (Jan. 2, 1794), in Paris pendant la Terreur: Rapports des agents secrets du Ministre de l'Intérieur, ed. Pierre Caron (Paris, 1910-64), 2:143-44.

36 François Furet, "Gouvernement révolutionnaire," in Dictionnaire critique de la Révolution française: Institutions et créations, ed. François Furet and Mona Ozouf (Paris, 1992), 241.
} 
audience endorses Tartuffe's accusations against Orgon in the name of revolutionary justice aimed above all to punish the enemies of the state. Tartuffe's arrest by "a municipal officer" was applauded for the same crime of treason. The audience's reception of Tartuffe in this instance seems similarly to have been ruled by "circumstantial necessity"-in other words, not by fascination or disgust with the vile behavior of Tartuffe, or by amusement and pity for Orgon's plight, but by the enjoyment of an abstract application of acts of denunciation and arrest.

I have noted that La Harpe points out that Tartuffe, having committed no crime, can only be punished by the exceptional measures at the disposal of a king. During the Terror the revolutionary government similarly displayed extralegal powers to punish "vile slanderers" for crimes against "true patriots." We might pause here to consider this homology. "Under the Old Regime," writes François Furet, "the idea of public safety came from the absolute authority of the king; under the Revolution, it supported a dictatorship employed in the name of the people. The two regimes were fueled by comparable situations or identical pretexts. They have in common putting public usefulness above the law and accepting the arbitrary actions of the state as the price for its efficacy." ${ }^{37}$ In this sense, even these sizable revisions to the denouement of Tartuffe do not effect a real transformation of the terms by which Tartuffe will be punished in the absence of a prince. The next clues to appear about revisions to the text surface in 1798. Here law is emphasized as the principle by which Tartuffe is judged, but again the Old Regime retains its power over the text.

According to a 1798 article in Grimod de La Reynière's Censeur dramatique, "for the last five years, these verses [the denouement of Tartuffe] have been altered in ten or twelve different ways. In 1794 it was the intervention of the Revolutionary Tribunal, two words that were strangely discordant with Molière's verses." This confirms that it had been the practice to cut the officer's speech in its entirety. Grimod continues: "These days it is customary to remove only the first twenty-eight verses of the officer's speech, for which are substituted eight or ten verses that signify nothing, but in which it is the law that does everything, and just in time." 38

Even if "only" the first twenty-eight verses are eliminated (suggesting for Grimod an improvement over previous cuts), replacing the authority of the monarch with the law remains troubling for the editor of the Censeur dramatique. Grimod argues that the law cannot intervene 
against Tartuffe because "what Molière gives a king to say cannot be transferred to the law, as it is a metaphysical entity that can neither 'pardon an offense' [5.7.1936] nor 'remember one's virtues' [5.7.1943]." 39 He also takes issue with replacing roi with loi because, if the latter noun is used, "one must not, in the twelve verses that follow [5.7.1932-43], use the pronoun $i l$, which is repeated four times, as it does not agree in gender with the feminine loi." 40

Now, the $i l / l o i$ disagreement is glaring in French, so naturally it elicits a response from an attentive reader. The correspondent writes-referring to the first time the pronoun appears in the speech (5.7.1932) - that $i l$ was indeed used, but only once and only to refer to Tartuffe, not to the law. This was made clear onstage by the actor, who as he spoke used a gesture to indicate Tartuffe. The editor of the Censeur dramatique responded to the reader that, no, the author of the article had been sitting in the front row and had distinctly heard the masculine pronoun used repeatedly, as he reported in his article, to refer to the law. ${ }^{41}$

What is happening here? Did the actors substitute elle for $i l$ as necessary in the officer's speech? Did the auditor's familiarity with the play make $i l$ an anticipation instead of a reality? Is the power of an expurgated prince such that an elle is spoken and an $i l$ is heard? Moreover, why is Grimod concerned, on the one hand, by the thoughtful question of the nature of the law and, on the other, by a grammatical annoyance? Perhaps these two issues are not unrelated. A closer look at the officer's speech shows that indeed, if one eliminates the first twenty-eight lines, the speech begins by referring to the character Tartuffe: "Oui, de tous vos papiers, dont il [Tartuffe] se dit le maître" (5.7.1932). The remaining four pronouns refer to the monarch $(5.7 .1933,1934,1938,1943)$. Moreover, there are two objects (lui), one referring to Tartuffe (5.7.1935) and the other to the prince (5.7.1942). In short, the last eighteen verses of this speech are innately susceptible to deictic confusion-a referential disorder that the attempt to erase the king from the speech only exacerbated and that the actor's physical gesture failed to overcome. The deeper sense of this linguistic confusion is suggested by the intriguing juxtaposition of Grimod's two seemingly discrete complaints. The law, that stubbornly abstract "metaphysical entity," is incapable of remembering and forgiving, as Grimod correctly points out. To endow the law with volition - as happens when the prince is replaced with the law-

39 Ibid., 148-49.

40 Ibid., 147-48. Il is actually repeated five times, in 5.7.1932, 1933, 1934, 1938, and 1943.

41 Censeur dramatique, 20 germinal an VI (Apr. 9, 1798), 261-63. 
is disturbing because to do so personifies the law and thus invokes the potentially arbitrary will of an individual. The ungrammatical $i l$ is the trace of that individual expunged from the speech. The monarch is amputated from the play, but he haunts the denouement - like a phantom limb-in the form of the pronoun $i l$.

The alterations to the denouement of Tartuffe thus failed to perform the shift from monarchial intervention to republican jurisprudence. Some implications of this failure are suggested by an interesting exchange of letters in the Journal des thêatres toward the end of 1798. The debate begins with a letter from a reader who argues that the theater, while it can inspire spectators to hate vice and love virtue, has no business with criminal behavior and should not attempt to address something that only the law can properly punish. Comedy should unmask vice in all its seductive colors, but "where the authority of the law begins, there ends the influence of the playwright." 42 Another reader countered that exposing crimes, not just socially undesirable behavior, is precisely what Molière does in Tartuffe. Tartuffe's scheming is not just a passing vice, he insists, but a crime. This is proven by the fact (and here the circular reasoning is apparent) that the law intervenes at the end of the play: "Taking one of his best comedies, perhaps his greatest, Tartuffe, I see not merely a harmless vice or an amusing rascal but an infamous hypocrite, ungrateful toward his benefactor, a wife seducer and a thief. Molière did not stop where 'the authority of the law begins,' because the denouement is achieved by the intervention of this same authority. One cannot deny that Tartuffe is a man for hanging." 43

In a final counterresponse, the first author notes that Tartuffe is not, in fact, a criminal, even if his schemes merit "universal animadversion." The correspondent points out that Tartuffe has the law on his side. The intervention of the prince at the end of the play is therefore a perversion of the law. The monarch abused the law in the name of moral correction:

The government, aware of [Tartuffe's] nefarious machinations, appalled by the horrible abuses of confidence perpetrated by this scoundrel, this traitor to those who gave him board, transgressed the law in order to punish this monster on moral grounds, and with a lettre de cachet removed him from society. This is the truth of it, and I will add that Molière has always been reproached for this denouement and with good reason: the law has no business resolving a comedy. ${ }^{44}$

42 Journal des théâtres, 11 frimaire an VII (Dec. 1, 1798), 6.

43 Journal des théâtres, 21 frimaire an VII (Dec. 11, 1798), 46.

44 Journal des théâtres, 23 frimaire an VII (Dec. 13, 1798), 55. 
On the one hand, therefore, we have an argument that recognizes the indelibility of the Old Regime in the text: the title character is not a criminal; he is guilty of a social vice, and only with the special powers at the disposal of a king - the lettre de cachet-can he be punished for the public good. On the other hand, the authority of a new sovereignty reconceptualizes Tartuffe's behavior as criminal and thus punishable by law. I suggest that if Molière was "rewritten," if revolutionaries succeeded in erasing Old Regime authority from his legacy, they did so in instances like this criminalization of Tartuffe. Not surprisingly, the same correspondent adds that Tartuffe is not the only example of criminality in Molière's plays. One need only look at the scheming valets and eloping lovers to see crime everywhere: scams, thefts, even kidnappings - all of them punishable by law. The representation of crime, the correspondent is saying, is all over Molière's work. In other words, Molière is no longer a painter of the social trespasses of the Old Regime that were once disciplined at the discretion of a monarch; he is now the denouncer of Old Regime crimes, punishable by the rule of law.

\section{Conclusion}

To conclude, I wish to reentangle the revisions of both history and literature, emphasizing them again as complementary processes. Rewriting the history of Molière's career appears more coherent than rewriting his literature. The paradox, forged by the events of his career, that Molière was powerful yet persecuted was exploited by revolutionaries to appropriate for the new nation this premier figure of Old Regime culture. His close alliance to the monarchy might have troubled his successful relocation to the shifting mosaic of revolutionary approbation. But in the incoherencies of Louis XIV's sponsorship, in the interstices where Molière was persecuted by his contemporaries, the revolutionaries found what they needed to rewrite an important aspect of the history of his career by aligning him with republican ideals. In opinions expressed in debates about government legislation of the theater, this ran the gamut from moderate viewpoints that acknowledged some association between the genius of Molière's art and the patronage of Louis XIV, to a more extreme view in which Molière not only owed nothing to his time but wrote his plays in seething anger over his forced servitude to the monarch. However coherent these revisions of history may appear, the revisions to Tartuffe tell another story. While the history of Molière's career becomes the means by which to illustrate the abuses of the Old Regime and to celebrate the authority of the law, his masterpiece Tartuffe refuses to cooperate in this construct. Here, liter- 
ary revision exposes the fragility in the reinterpretations of the past that historical revisionism aims to achieve.

\section{Appendix. Tartuffe 5.7.1904-43}

Remettez-vous, Monsieur, d'une alarme si chaude.

1905 Nous vivons sous un Prince ennemi de la fraude,

Un Prince dont les yeux se font jour dans les coeurs,

Et que ne peut tromper tout l'art des imposteurs.

D'un fin discernement sa grande âme pourvue

Sur les choses toujours jette une droite vue;

1910 Chez elle jamais rien ne surprend trop d'accès,

Et sa ferme raison ne tombe en nul excès.

Il donne aux gens de bien une gloire immortelle;

Mais sans aveuglement il fait briller ce zèle,

Et l'amour pour les vrais ne ferme point son coeur

1915 A tout ce que les faux doivent donner d'horreur.

Celui-ci n'était pas pour le pouvoir surprendre,

Et de pièges plus fins on le voit se défendre.

D’abord il a percé, par ses vives clartés,

Des replis de son coeur toutes les lâchetés.

1920 Venant vous accuser, il s'est trahi lui-même,

Et par un juste trait de l'équité suprême,

S'est découvert au Prince un fourbe renommé,

Dont sous un autre nom il était informé;

Et c'est un long détail d'actions toutes noires

1925 Dont on pourrait former des volumes d'histoires.

Ce monarque, en un mot, a vers vous détesté

Sa lâche ingratitude et sa déloyauté;

A ses autres horreurs il a joint cette suite,

Et ne m'a jusqu'ici soumis à sa conduite

1930 Que pour voir l'impudence aller jusques au bout,

Et vous faire par lui faire raison du tout.

Oui, de tous vos papiers, dont il se dit le maître,

Il veut qu'entre vos mains je dépouille le traître.

D'un souverain pouvoir, il brise les liens

1935 Du contrat qui lui fait un don de tous vos biens, Et vous pardonne enfin cette offense secrète

Où vous a d'un ami fait tomber la retraite;

Et c'est le prix qu'il donne au zèle qu'autrefois

On vous vit témoigner en appuyant ses droits,

1940 Pour montrer que son coeur sait, quand moins on y pense,

D’une bonne action verser la récompense,

Que jamais le mérite avec lui ne perd rien,

Et que mieux que du mal il se souvient du bien. 